\title{
A Cup of Tea
}

My mum and my aunties sit around Nanny's kitchen; her old wooden table sprawled with marg, salads, buns and an assortment of meats.

The buns from the bakery department of Pak'n'Save have been ripped open and are being stuffed to the brim with anything they can get their hands on.

Mum begins to giggle lightly, just out of pure excitement for the contents she's decided to place in her bun. She looks up and across the table at her older sister Kay, who is testing the mayonnaise from this flash new Thai style coleslaw.

In between mouthfuls of slaw, Aunty Kay looks down and across at the full table,

"Mum's had this cloth for so long, I'm pretty sure it's older than me!"

All of the sisters laugh as I reach for an old brown plate in the middle of the table. The plate itself is in the shape of a flounder and has last night's roast piled atop of it. "Luckily Uncle Larry and them didn't come over last night," I say, changing the subject, "Otherwise there'd be like, next to no chicken left." With my cheesy bun in hand I swipe a quick layer of Nanny's homemade beetroot chutney from an old jar that used to be full of apricot jam. The chutney is spicy and bitter, probably because the beets themselves come from Mum's eldest sister, who is undeniably spicy and bitter herself.

I lick the knife on both sides, gliding my tongue against the cold steel and start to think to myself that I rather like my Aunty's short temper and my Nanny's chutney about the same. 
"Better watch out," Mum starts, breaking my train of thought. I look up at her cutting up some red onion and I already know what is coming out of her mouth next.

"Or you'll slice your tongue in two, and will be able to lick both sides of your bum!"

The table erupts with laughter, the sisters are slapping their knees and stomping their feet in amusement of Mum's warning, and I roll my eyes as far back as they'll go. "I used to say that to you when you were younger." Nanny struggles to get out between her breathless wheezes. She's laughing so much she has to leave the kitchen to go get her inhaler.

"I can't believe that you say that to your kids, Terri!" My Aunty Nicki chimes in.

"It doesn't even make sense," I say protestingly as I chomp down aggressively on my bun.

More laughter ensues and before we know it, we're louder than Pāpā's television set in the next room. The blaring voices seem so merged it's hard to make out what he's even watching. I pop my head around the corner of the kitchen to check in on him and make sure he hasn't snuck out into the garden or up the road somewhere. Sure enough, there he is, still sitting in his green lazy boy chair as always. To his left, a footstool with a tapestry thrown across it. The tapestry was hand-sewn by Nanny and depicts four jack russels in a field.

Stacked on top are various different puzzle books from every two dollar store in Gisborne. Each page demolished with scribbles from Pāpā's ample supply of blue pens.

To his right, dividing the space of lounge between his green Lazy Boy chair and Nanny's pink chair of the same make is a shared side table. On it, is an old speckled mug and this week's television guide, with the Sunday night movie Pride and Prejudice, circled twice. There's a small woven basket in the middle with Nanny's reading glasses, a nail file and two tupperware containers, neatly tucked in the back, one for Nanny's hayfever medication and the other jammed to the brim with Pāpā's licorice all sorts. 
I throw a quick gaze around the room as the afternoon sun streams in through the large windows and netted curtains. Photographs of my Pāpā's nine siblings, six children and a multitude of mokopuna plaster the yellow, poorly wallpapered walls around him.

Pāpā makes a deep grunt sound as he tries to adjust himself in his chair. I watch him shuffle around in place uncomfortably. I close the door between the lounge and the kitchen so he can watch his TV without the sound of gossip. Pāpā doesn't need to hear about what Nanny Pat had told Nanny last time she was at the marae.

I slide the door shut and Pāpā looks across the room at me.

"Aw, thank you my darling," He says softly.

Before sitting down in Nanny's chair, I bend over and give him a quick little peck on the cheek. He places his old sunken hand over mine and squeezes it slightly before letting it go again. He watches me sit down and then returns his attention back onto the TV.

His back is slouched, his eyes are fixed straight ahead on an old Uawa and Patutahi rugby match. As the game progresses, he's swearing and cursing at the players, referees, and people he recognizes in the crowd. With his bottom lip jutted out and his eyebrows raised he's making a fool of everyone on the pitch with his quick tongue and koroua humor.

Some boy barely seventeen who doesn't know how to kick has been driving him wild for the entire half. The commentators begin doing player profiles and as soon as the young boy's picture and name appear on the screen, Pāpā begins to laugh and says,

"Oh yup, that'd be right, he's a bloody Tūpara! Those Tūpara's never kicked a ball straight in their entire lives!" By the end of the game, Pāpā is flicking through the channels indecisively, trying to decide between some soap drama from the '80s or a white woman's cooking show. I get up and out of Nanny's chair and head for the kitchen. Even with the door closed I can still hear my mum and 
her sister's chatting and laughing away at the table. From the door, I turn back around to Pāpā and call out, "Wanna cup of tea or somethin', Pāpā?"

He doesn't respond, so I grab the mug sitting on the side table next to him and repeat my questions holding the cup up as I ask.

"Do you want a cuppa or somethin', Pāpā?"

This time Pāpā hears and answers back immediately, "Oh yes please Babe, there's some peanut brownies in Nanny's cupboard too."

With his old mug in my hand, I open the door to the kitchen, closing it behind me. I head over to the sink, pour whatever remains in Pāpā's cup out and give it a little rinse.

My Nanny is standing there washing the leftover dishes from our afternoon tea.

Before living in these kaumātua flats, Nanny and Pāpā lived on a big farm in Nūhaka. The house itself was beautiful, and sat on a big lawn. It was just down the lane from our marae Te Rehu, and could easily be spotted from the busy road as there were always big beautiful rose bushes lining the fences surrounding it.

When I was younger my brothers and I would spend what felt like whole summers on the farm with Nanny and Pāpā. We always felt special being away from Auckland and either helping out around the farm with Nanny or riding with Pāpā on the horses. Our other cousins lived either in Mangatū, Ruatoria, Hawkes Bay or somewhere in between, so they got to see Nanny and Pāpā all the time. Our Mum was the only one out of her six siblings that didn't live in or around Gisborne. In fact, she had made it her life's mission to get as far away as possible from the coast.

Us city kids however, loved getting dropped off in the middle of nowhere at Nanny and Pāpā's house. Mum would always make sure to leave us stocked up with a couple bottles of fizzy for us and packet of lollies for Pāpā. My Pāpā was the best at riding horses and everyone in Nūhaka knew it. 
On the farm and in the community, my Pāpā was like a god, a minister and an entire choir rolled into one. Every animal and human within radius would hang on his every song and whistle.

As I'm preparing his cup of tea, I begin to think about my Pāpā now and how much he's changed. He's not as tall or broad anymore, his hands are wrinkled and weak, his legs and arms aren't as strong or long and his hair is sparse and grey. He wobbles when he walks and his days are no longer spent riding horses and building fences, but are instead replaced with mediocre television, crosswords and visits from people he doesn't even like.

I try to imagine myself in his shoes and I can feel my throat tightening up and tears welling. We all know he hates us seeing him like this and a part of me feels guilty for how little time I put aside to just sit and listen to him when he was still well.

The sound of the jug coming to the boil breaks my train of thought and I instinctively pour the hot water into Pāpā's mug. I feel my Mum come up behind me and place her dishes in the sink, giving them a little rinse and scrub.

"Is Pāpā alright?" She asks while placing her dishes in the rack to dry.

I look down at the ground and furrow my brow.

She looks at me quizzingly as I place the jug back in place and open the container of Nanny's peanut brownies.

I delicately place the brownies on top of a white side plate and reach for a few more old battered mugs before asking, "I'm making tea, does anyone else want one?" 